\title{
Focus on Central Afghanistan:
}

A Special Report prepared for the Office of the AID Representative for Afghanistan Affairs in Pakistan 
Preface

The following report is based primarily on two missions to Afghanistan, one from 27 September - 30 October 1990 and the second from 21 November - 14 December 1990.

During this period, I served as the representative of the United Nations office of the Coordinator for Afghanistan (UNOCA) in central Afghanistan. I was responsible primarily for developing a program for U.N. assistance to central Afghanistan for 1991. As UNOCA is a coordinating body, I was also charged with rallying support for surveys and project implementation in the various technical sectors - health, education, agriculture, demining, etc. - by the various U.N. agencies. I was the "Team Leader" for both missions with responsibility for planning each mission, arranging security, overseeing finances, and introducing the U.N. to local shuras and commanders inside Afghanistan.

I spent the summer of 1986 studying Dari at the Refugee Studies Programme at Oxford. During that period, I established contact with Hazara leaders in Quetta, who were keen to have a researcher learn more about the Hazaras and their history. With a fellowship from the Thomas Watson Foundation, I spent six months (1986-1987) conducting interviews with Hazara refugees in Quetta and in various camps in Baluchistan. Because of fighting I was not able to visit Hazara lands in Afghanistan at that time.

I returned to Quetta in March 1990 to serve as the Progam Manager for the Mine Awareness Program, a U.N. program administered by the International Rescue Committee. I remained there until September, whereupon I was offered a contract with UNOCA, which was in the process of establishing a presence in central Afghanistan.

During the two missions I covered 6000 kilometers in five provinces: Paktika, Ghazni, Wardak, Bamyan, and Ghor. As the U.N. office was in Bamyan, I spent most of my time there. The districts which I came to know best are Urgun (Paktika); Qarabagh, Jaghatu, and Nawur (Ghazni); Behsud I and II (Wardak); Lal-o Sarjangal (Ghor); and Panjao, Yakaolang, and Bamyan (Bamyan).

This report, then, focuses on central Afghanistan since that is tha area I know best. Many of the observations herein, however, particularly those concerning shuras and the delivery of supplies, reflect realities in other parts of the country. 


\section{Table of Contents}

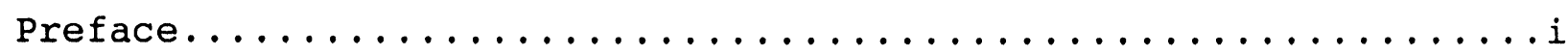

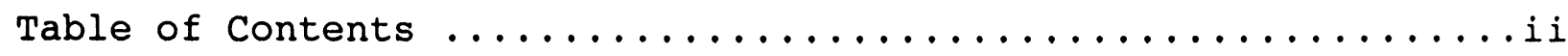

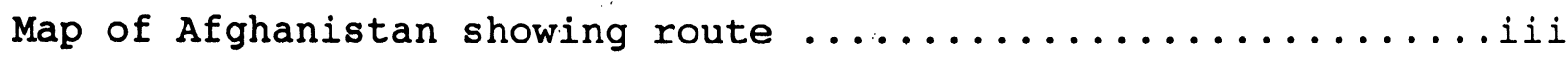

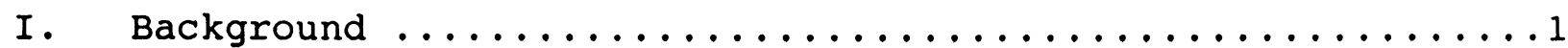

II. Routes, Infrastructure and Bazaars $\ldots \ldots \ldots \ldots \ldots \ldots \ldots . \ldots$

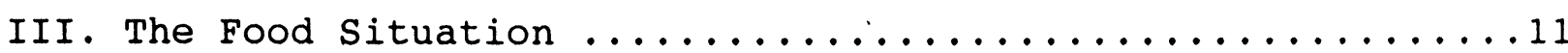

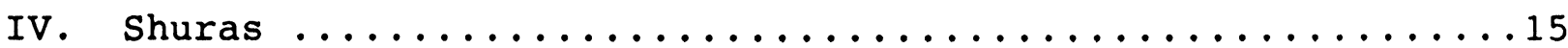

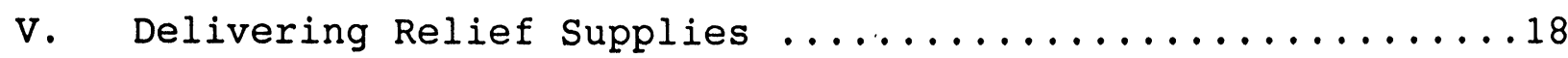

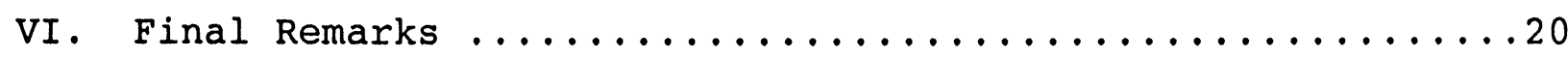

\section{List of Tables}

Table 1: Routes and distances: Peshawar to Bamyan .......... Table 2: Displaced people in central Afghanistan ..........12 Table 3: Selected commodity prices and food import trends ....14 


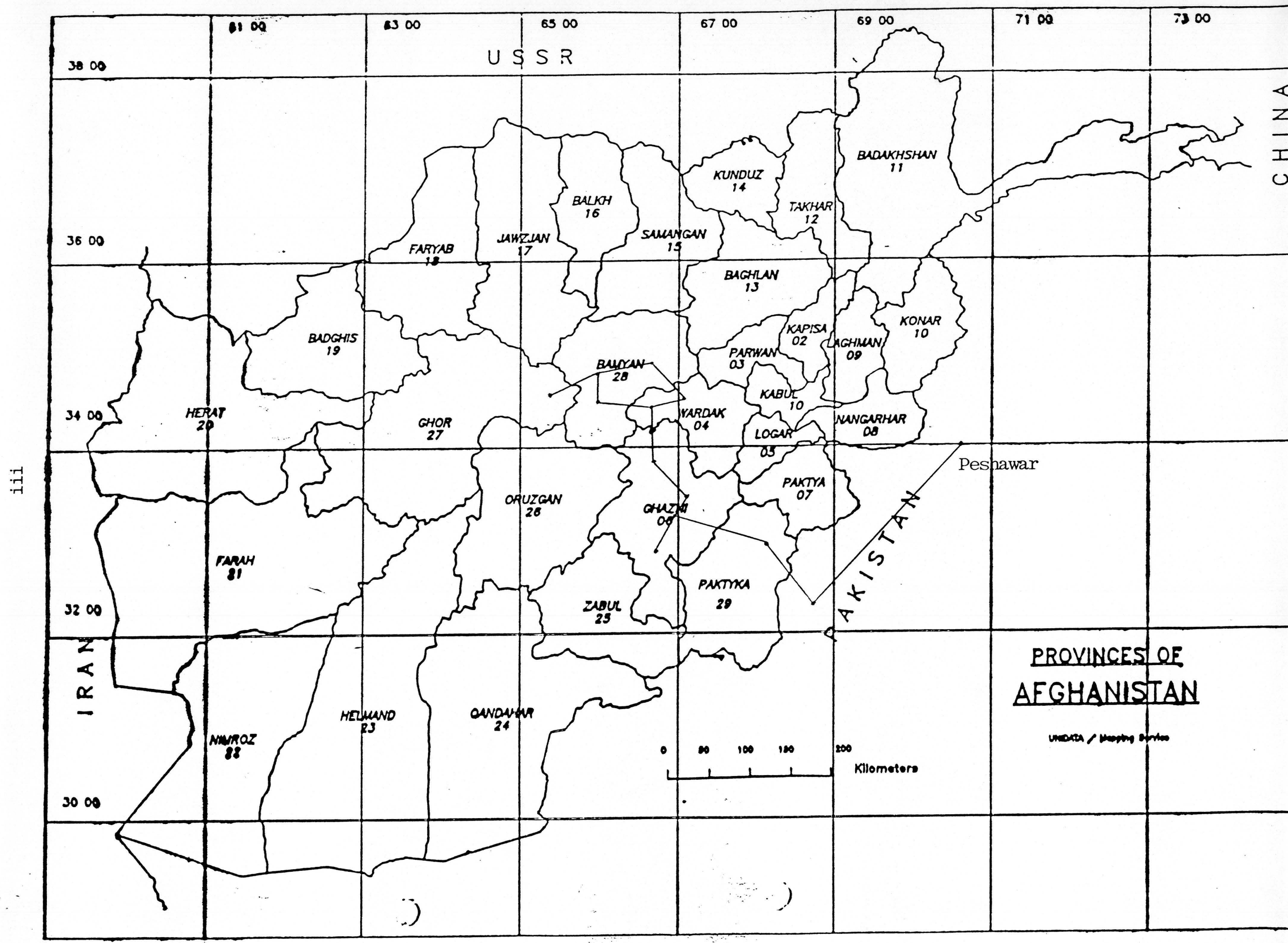




\section{Background}

Central Afghanistan is an intimidating landscape sliced by the Hindu Kush range. Altitudes range from 1800 - 5500 meters with most of the population living between 2000 and 3000 meters. Sources from outside the region place the population around one million inhabitants; the local people, however, insist that the actual figure is at least five times that.

The landscape is dominated by high mountains that rise steeply out of narrow valleys. In the smaller valleys, villages lie right at the base of the slopes; in the larger valleys, such as Bamyan, Yakaolang, and Lal, which are threaded by meandering streams fed by high snowfields, settlements are scattered throughout the valley floor.

The predominent ethnic group in the region is the Hazaras. They are Oriental in appearance compared to Afghanistan's dominant ethnic group, the Pashtuns, partly because of the movement of the Mongols in Central Asia in the thirteenth century. Unlike most other Afghans, Hazaras follow the Shia sect of Islam rather than the Sunni. Their mother tongue is Persian.

In the late nineteenth century, Amir Adbur Rahman, the "father of modern Afghanistan," launched several devestating wars against the Hazarajat, as Hazara lands are often called, in a bid to pacify the central region and solidify his rule.

Hazaras today remember the wars of Hazarajat as if they had all experienced them themselves. They have never forgiven the pashtuns for subjugating them and taking some of their lands, pushing them farther into the mountains. The Russian invasion of Afghanistan did not abate their fury; outsiders, particularly in the West, assumed that old and bitter feuds and hatreds could be set aside to thwart the common enemy.

The relationship between the Pashtuns and Hazaras is the most volatile ethnic relationship in Afghanistan today. Its latest manifestation was an eruption of fighting in southern Uruzgan and northern Zabul in early 1990 that displaced hundreds of people. Many of these internal refugees fled to Ghazni. Another manifestation is the ongoing rumor of greater cooperation between the Shia parties (which are Hazara, except for Harakat Islami, which is mixed) and the Kabul government, or of Najib's offer to give territories close to the Iran border to the Hazaras in exchange for their cooperation in further splitting the six-party alliance.

The Hazaras, then, are receptive to an outside hand offering to promote their cause; however, they also fear manipulation from outsiders. Because the Hazaras share cultural and linguistic links 
with Iran, and because the Soviet invasion coincided with the Iranian Revolution, Iran has been the major backer of Hazara/Shia nationalism in Afghanistan. In fact, because Hazaras have almost no representation in the Afghan Interim Government (AIG), Iran has been, in effect, the only backer of the Hazaras since 1979.

Excluded from the arms outflow from the West and Saudi Arabia, the Hazaras also turned to Iran for military support. Iran not only provided arms but assisted in the formation of several Shia parties such as Nasr (Victory), Sepah-i Pasdaran (Army of the Guardians), and Pasdaran-i Jehad (Guardians of the Holy War).

What Iran hoped to achieve in Afghanistan is not clear, but its involvement hastened disunity rather than unity among the Hazaras. By 1984, Iranian-supported parties had gained the upper hand over secular and "traditionalist" groupings, but several years of bitter internecine fighting ensued - far more fighting than took place against the Soviets or the Afghan government.

A major breakthrough occurred in 1988 when mujahideen captured Bamyan center, the first provincial capital to fall to the rebels. Shortly thereafter, all Shia parties active in central Afghanistan, except Harakat Islami, united, with the encouragement of Iran, under a coalition called Hezb-i Wahdat (Party of Unity). The Central Committee of Hezb-i Wahdat was to be based in Bamyan and draw together members from all districts of Hazarajat.

The formation of Hezb-i Wahdat is one of the most significant political developments in central Afghanistan since 1979. The bloody fratricidal warfare of the early and mid-1980's, warfare that claimed hundreds of lives and prevented any progress in reconstruction and development, has subsided. A fragile peace has settled over central Afghanistan. 
II. The Route, Infrastructure, and Bazaars

The distance from Peshawar to Bamyan center via Panjao and Yakaolang is 1253 kilometers. The more common route is via Dahane Abdalla and the Haji Gak Pass, which shortens the trip by 200 kilometers. The latter route has been driven in its entirety by U.N. staff in three days; however, five days from Peshawar to Bamyan (by Land Cruiser) via either of the two routes is the norm.

Table 1 provides an overview of the condition of roads in parts of eastern and central Afghanistan. The average travelling speed in Afghanistan is thirty kilometers per hour. Wana, a Waziri area, is the most common jumping-off point into eastern and central Afghanistan. (The Waziris, found on both sides of the border, are generally pro-Najib. It is alleged that the Kabul government rewards them for destabilizing the area since it is a major transit point for weapons. Roads on both sides of the Pak-Afghan border are frequently closed for short periods, but not always because of the hidden hand of Kabul.)

There are two routes from Wana to Angur Ada, the bustling bazaar town that marks the border: via Azam Warsak (a turbulent area but usually passable) and via Shah Alam. The second is shorter by thirty minutes but both are rough, heavily travelled dirt roads. Pavement disappears thirty minutes outside of wana and is not seen again until the Kabul-Qandahar-Herat highway in Ghazni, the country's only paved road outside of Kabul.

Several routes radiate out from the bazaar in the general direction of Urgun, 70 kilometers away. The drive takes threee hours over rough road and river beds, although at Sarobi, one hour shy of Urgun, there is a sudden and very brief burst of improved road. The Danish NGO DAACAR started road building here with the intention of connecting Sarobi with Urgun, but this project has been abandoned.

The route between Wana and Urgun is the only stretch of the entire journey to central Afghanistan that can be called "forested." Junipers cover the hillsides until one drops into the broad, unforested (deforested?) valley of Urgun, which sits at 2200 meters.

Urgun has the appearance of a ghost town, except in the early morning and late afternoon, when the bazaar is crowded with trucks and the three hotels are full of overnighters. The town, a district capital, is spread over a wide area, but there are virtually no inhabitants. There is a shura here, but most of the district's residents are in Pakistan while their fortress-like houses, once surrounded by high mud walls, have fallen into disrepair and are being eaten away by the weather. Former government buildings have been bombed, although some rooms and the 


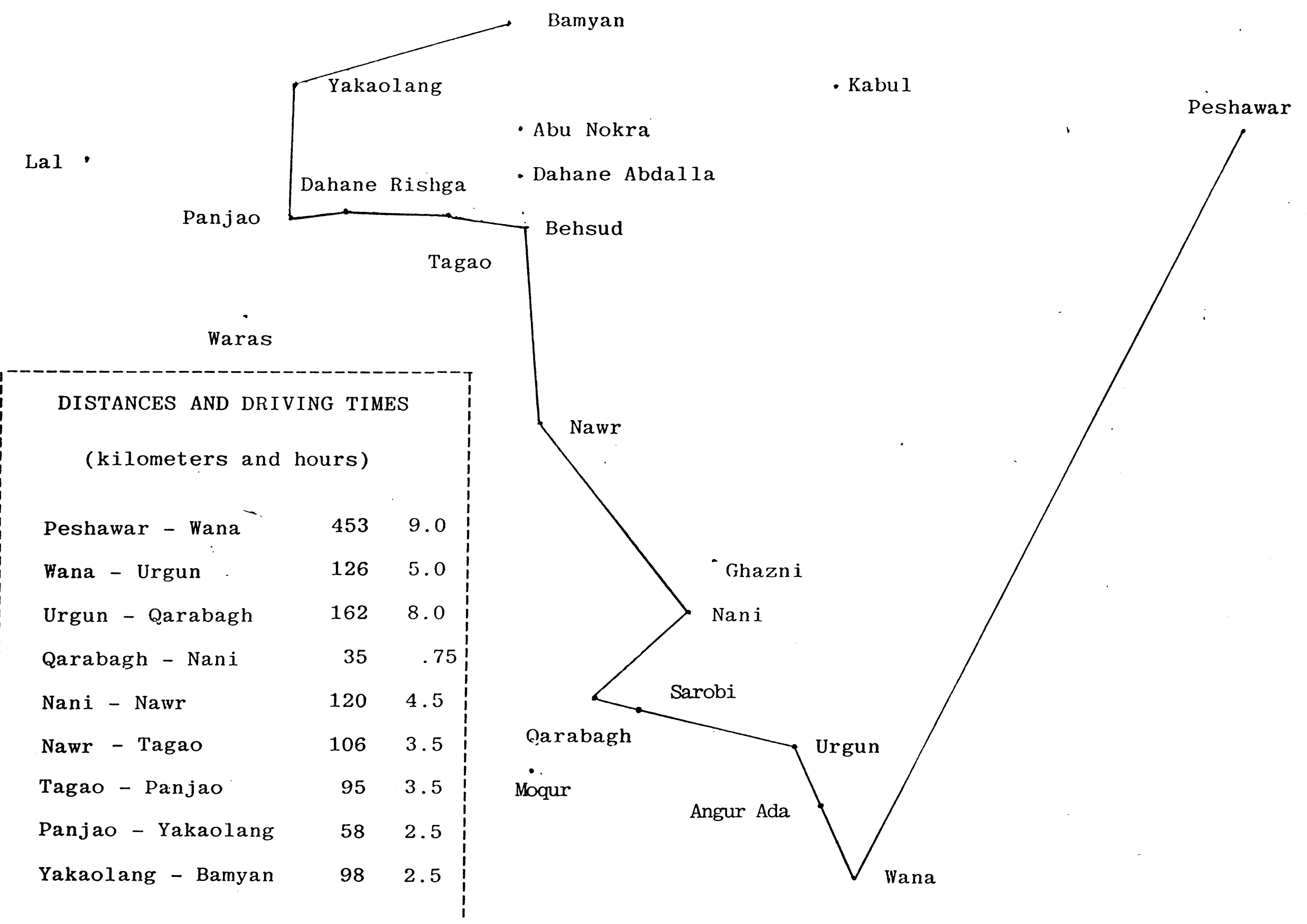


large aluminum storage facility are still useable.

Urgun is a heavily mined district. U.N. demining teams have been active in the area since the summer, using both mine-sniffing dogs trained in Thailand and flails manufactured in Scotland. A flail is a heavy tractor that slaps the earth with chains on a rotor to set off mines. It can clear a stretch 700 meters long and 3 meters wide every hour. The major transit routes from Angur Ada are generally mine-free, but one has to be cautious when walking off of the road.

The stretch from Urgun to Qarabagh is the roughest of the entire journey. An Afghan NGO has been slated to improve the road but has made no progress. Average travelling speed is twenty kilometers per hour. One can proceed via Zarghun Shah or Sharan, but both routes are equally agonizing, primarily because the first half of the trip takes one over stream beds.

Life in the Katawaz plain (the valley of Zarghun Shah), which runs from paktia to the $z$ abul border, has the appearance of normalcy. While not densely populated, this is clearly an area that has produced few refugees (or perhaps the refugees have returned). The bazaars of the major villages - Yusuf Khel, Yahya Khel, and Mush Khel - were amply stocked and lively without the conspiratorial air of Angur Ada.

From the Katawaz plain, the road proceeds over ranges of low mountains to the Kabul-Qandahar highway. Depending on which dirt track one has taken, one reaches the highway either at Qarabagh or at Nani. The Nani route takes one along the outskirts of Sharan and through Band-i Sarday, where the government once had an irrigation project. There is a large reservoir outside of town with solid cement buildings at one end that perhaps once housed the project's employees. Driving through town one sees an astonishing sight: heavy equipment such as cranes and tractors. The machines sit idly behind fences, but for the first time one finds oneself in an area reminiscent of the twentieth century.

Qarabagh and environs appear prosperous. Other than piles of red stones indicating mines (placed by demining teams), there are no signs of warfare, past or present. The mines, however, are set in amongst the people, along the major thoroughfares and paths, even right outside the bazaar. Once could easily overlook the markings at night, except that people throughout mujahideen areas rarely move about after dark. The citizens of Qarabagh go about their business as if the mines were not there.

The bazaar consists of two rows of mud shops with heavy, padlocked wooden doors. It features a pharmacy, a clinic, several hotels, butcher shops, auto parts and repair, a dentist, and bicycle shops. One can buy several varieties of rice and tea; nuts - almonds, pistachios, peanuts; eggs; biscuits; shampoo; 
nailclippers; pocketknives; Chitrali caps; shoes and ill-fitting clothing - in short, anything to get by and a little extra. Almost all of the supplies come from Pakistan (except the fresh products such as potatoes, onions, nuts, and meat) and are only slightly more expensive inside Afghanistan.

The same is true in Moqur and Nani, an hour south and north of Qarabagh, respectively, on the highway. The bazaar in Moqur is even larger than the one in Qarabagh, partly because it is situated directly on the highway, whereas Qarbagh is tucked away a kilometer off the road. Nani, in turn, is a truck stop, also with an abundance of basic commodities and foodstuffs. The merchants in all three bazaars have converted cargo containers, which often have "USA" printed on them, into shops.

The highway itself between Moqur and Nani, a stretch of 80 kilometers, offers the traveller a mixture of nausea and exhilaration. In some stretches, the pavement has been bombed into invisibility, producing craters every few feet that one rides like a ship on stormy seas. The pavement then abruptly reappears and for ten or twenty kilometers one can drive at any speed.

The second half of the journey takes one into the mountains ane valleys of central Afghanistan and from Pashtun lands into the Hazarajat. The terrain becomes more rugged. The bazaars are relatively sparse until one reaches the crossroads of Dahane Abdalla, a day's drive south of Bamyan. After Nani, one is unlikely to see any signs of mechanization, except for trucks and the occasional bus. The villages are smaller and more isolated. There is no equivalent of the Moqur-Qarabagh-Nani stretch in terms of population density and level of development in all of central Afghanistan.

The roads are surprisingly good in the Hazarajat considering the terrain. Instead of meandering through broad vallys and stream beds, roads in the central region - all unpaved - cut across high plateaus, wind through narrow valley openings, and traverse rivers. From December to April, however, most roads are completely impassable, such as the important route over the Haji Gak Pass ( 3000 meters). In addition, the paucity of bridges makes travel extremely difficult in the spring. I saw only one bridge, across a tributary of the Helmand River in Behsud district (Wardak), that was built with cement and had a lifetime of more than two years:

Shuras in central Afghanistan are profoundly aware of their physical isolation. Not surprisingly, in my dealings with shuras in many districts, the topic of roads and bridges came up more than any other in discussions of assistance. Shuras throughout Hazarajat are particularly keen on roads that would facilitate access to the north, especially to Mazar-i Sharif, but there is no equipment other than hand tools to work with. 
From Nani the next major bazaar is Nawur. En route one passes Dasht-i Nawur (the desert of Nawur), an enormous, sparsely inhabited depression said to be one of the coldest places in Afghanistan. Entering the town one passes through a checkpost (a rope suspended between two poles) before reaching the main bazaar. Like Nani, Nawur has the feel of a truck stop, but unlike Nani there is no adjacent highway. In Nawur the dusty road seems to come from nowhere and go nowhere.

Passing north of Ghazni province, one gradually moves into the economic orbit of Kabul. Dahane Abdalla, another small but bustling bazaar with barrels of diesel, cubes of salt, and bags of rice and wheat stacked along the road, marks the transition. Markaz-i Behsud (Behsud center), however, a few hours south of Dahane Abdalla, is reminiscent of Urgun in its level of depopulation. It is one of the two districts of central Afghanistan (Jaghori in Ghazni is the other) that produces the most Hazara refugees. There are no signs of life in the bazaar except for a mujahideen office.

West of Dahane Abdalla the route proceeds along a tributary of the Helmand into the heart of Hazarajat; north one crosses the Haji Gak Pass before entering the valley of Bamyan under the Red City, a cliff-top fortress ransacked by Genghis Khan. East is the route via Tezak to Kabul.

West of Yakaolang there used to be a road via Chagcharan (Ghor) to Herat, but Chagcharan is controlled by the government, which necessitates a wide detour. Routes west are insecure and rough enough that Hazaras seeking employment in Iran exit to Pakistan via Qarabagh and Angur Ada first, then proceed to Quetta and the Iranian border at Taftan.

The main towns in Bamyan province are Panjao, Yakaolang, and Bamyan itself. All have substantial, well-stocked bazaars, especially Bamyan, which is a day's drive from Kabul. The goods in these bazaars come almost exclusively from Kabul. Bamyan even has one luxury-goods store that sells Indian wool shawls and Dutch Pepsi.

Lal-o Sarjangal in Ghor province, about four hours from Yakaolang, also has an impressive bazaar that, unlike any other I saw, snakes over two rises. Here one can buy tart green apples in addition to other basic items. Clothing shops were in abundance. There was also a library with several thousand volumes on history, literature, and religion (one book was in English, the rest in Persian). The only other library I saw was in Bamyan; it was established in late November 1990 in commemoration of a prominent member of Hezb-i Wahdat recently assassinated.

Bamyan, Yakaolang, Panjao, and Lal all have useable airstrips for small aircraft. The Bamyan airstrip is now ringed with white 
stones, and the U.N. has placed a large white Rubb Hall tent next to it. A six-seater U.N. plane landed in October 1990 to remove an injured deminer, the first airplane to come to Bamyan in two years. The Yakaolang airstrip is in disrepai but a superior alternative exists on the top of a plateau half an hour from town. The remains of a government aviation office blasted by a Russian tank stand next to the Panjao airstrip, while in Lal the airfield needs to be cleared of stones, but it is operable now. Shuras in these areas are all in favor of using these airstrips.

Another resource found in these central districts but not elsewhere is a telephone line. It links Lal, Panjao, Yakaolang, and Waras. The central exchange is in Panjao.

As for health facilities, the only hospitals I know of are an ICRC post in Nani and a relatively sophisticated hospital in Bamyan run by a small party of intellectuals called Jabha-e Mustazifin. ICRC has other posts in Maidan, Zabul, and Qandahar, but I have not seen them.

The hospital in Bamyan is staffed by two male and three lady doctors who can perform surgery. The deminer who stepped on a mine in Bamyan in October was treated here before being evacuated by air to Kabul. Locals complain that the hospital charges for treatment and medicine, which few people can afford. Hospital staff, in turn, say they have no choice since they receive no assistance from the outside. MSF/France had a clinic in Bamyan but were supposedly run out over the summer by Mustazifin because the party wanted a monopoly on health services. MSF turned their supplies over to the Islamic Shura of Bamyan, which has requested assistance from the U.N. since they have no doctor at their disposal.

In Yakaolang, the German Afghanistan Committee has taken over a medical facility also vacated by MSF (MSF left yakaolang following the closure of its entire Afghan program in 1990). According to the hospital administrator, Jaffar Khan, GAC agreed to supply medicine and salaries for two years. GAC sent about twenty boxes of medicine from Peshawar in November, most of which arrived. The hospital and the nearby staff rooms were built by the Americans in the 1960's (?) and are among the most solid public buildings in central Afghanistan.

The German Afghanistan Committee's intervention in Yakaolang was timely. With health facilities so scarce throughout Afghanistan, it would have been especially regrettable that an established hospital with experienced staff would have had to fold with the departure of its patron. Fortunately, GAC was able to step in where MSF left off; otherwise, the staff would probably have left for Pakistan.

Another GAC facility I visited, however, was badly situated and appeared to be abandoned. The clinic was five kilometers west 
of Dahane Abdalla at Seya Buta but sits atop a hill next to a Nasr base. Not only is it clear that the commander controls the clinic but there are no people around as well. There were no signs of life at the clinic although the commander told me that a German "delegation" had passed through only a few days before. I saw no reason why GAC "gave" the commander a clinic when the bazaar at Dahane Abdalla only five kilometers away had none.

Panjao and Lal have buildings (with signs) for clinics but no medicine. Like Yakaolang, Panjao has an American-built hospital, but it is not operating. There are no supplies. The administrator studied medecine in Japan for a year but is currently unemployed. The British NGO LEPCO operates a leprosy control center in Lal (and in Jaghori district of Ghazni) which also sees patients with other ailments. However, the shura in Lal was keen to breathe life into its clinic.

The French NGO AVICEN, the International Medical Corps (IMC), and Management Sciences for Health (MSH) have all established clinics between Qarabagh and Bamyan. AVICEN, which focuses on vaccination, is the most active NGO in all of central Afghanistan, having recently branched out into food distribution as well. A Hazara woman, Dr. Sima, who has studied in the U.S., has a clinic in Jaghori district and is supervising the construction of a hospital there.

Yet the general sense one has is that eastern and central Afghanistan are both woefully short of health facilities. Most people buy medicine from the local pharmacy, trusting the advice of a pharmacist who may or may not have had any training, or, for more serious cases, go to Kabul or Pakistan. Nevertheless, I would say that most people in eastern and central Afghanistan can get to some sort of medical facility and receive semi-accurate advice within one day's drive from their village (finding transportation is not a given, unfortunately).

Political tensions, however, can obstruct mobility, particularly for adult males; they risk being conscripted or otherwise detained if they travel to Kabul, whereas other sectors of the population can move in and out of the capital relatively easily. With the exception of the Bamyan hospital and perhaps Dr. Sima's clinic in Jaghori, all health facilities I encountered or heard of in eastern and central Afghanistan are dependent on outside assistance.

Schools are more prevalent although there is a shortage of supplies and furniture. Classes are held wherever space is available: mosques, homes, outside, or in actual school buildings. Shuras invariably told me that teachers were available in the district and were unemployed. Those who do have teaching jobs are often paid in kind, such as with wheat or firewood. 
In contrast to the health sector, most schools run without any outside assistance. The Swedish Committee of Afghanistan (SCA) is the only NGO I encountered although records indicate that the Univerity of Nebraska (UNO) and Muslim Aid are active in Ghazni. These agencies are not in a position to provide buildings, but they can provide supplies and salaries.

Hazaras are recptive to female educaton. I was very impressed with a girls school I visited in Lal, although the only supplies in evidence were a blackboard and chalk. The teachers were a husband and wife team.

A Hezb-i Wahdat representative from Shahristan district, Uruzgan, told me proudly that there were eight girls schools in his district. If so, that must be one of the highest figures for any district in Afghanistan.

There was no electricity or running water in any area I visted. The local people use gas lanterns at night. Lanterns and flashlights were available in every bazaar I visited. 


\section{The Food Situation}

My experience in Afghanistan indicates that there is no widespread food shortage in the country. I saw no signs of malnutrition, and I was generally impressed with the food stocks in the bazaars. Rarely did shuras list emergency wheat as a priority for assistance.

I would not suggest, however, that food is abundant in all places and for all people. Hazaras in particular must work very hard, using basic tools and techniques, to eke out a simple living from the harsh land. They are poor and their lives difficult, but they are not as badly off as the peasants Tawney described in his famous characterization of rural life as "standing up to one's neck in water so that the slightest ripple drowns you."

There were also signs of a healthy harvest in parts of central Afghanistan. I often witnessed what must be a perennial late autumn ritual: the whole family out in the fields cleaning the wheat on heavy carpets, the boys and donkeys returning from the hilltops with full loads of shrubs for winter burning.

However, I never ventured far from the roads, and most of my contacts with the local population were with the least vulnerable sector: adult men. I also suspect that another perennial late autumn ritual is the departure of sons and husbands for Pakistan and, in the case of the Hazaras, for Iran also. Groups of refugees I encountered (see Table 2) on the second mission frequently cited lack of food as a pretext for departure. These people clearly were not starving; what they were reacting to, I believe, was poverty and the harshness of winter, with both its unemployment and its boredom. With the family having just enough to get by, every mouth to feed is a burden, so those who can leave do, often to return in the spring.

Central Afghanistan, nevertheless, is not a high refugeeproducing area. Roughly 808 of the population is still in place. It has not seen heavy warfare from the Soviets or the Afghan government, except in Bamyan. The relative stability of the population reflects the general adequacy of living conditions, at least in face of the alternatives.

There are, however, pockets of perhaps severe food deficit. They tend to be in areas far from roads, in areas struck by natural calamity, and in areas where fighting continues. Those I know about are the following:

1. Yakaolang district, Bamyan. U.N. staff members visited the village of Sare Tarnok on horseback in June. The UNOCA representative wrote that "local people said they had lost 300 jeribs of cultivable land, and that one-quarter of the remaining 
Table 2

Displaced people in central Afghanistan: November - December 1990 (as recorded by U.N. mission)

\begin{tabular}{|c|c|c|c|c|c|c|c|}
\hline \multicolumn{2}{|c|}{ date } & \multirow{2}{*}{$\begin{array}{l}\text { where seen } \\
\text { Wana }\end{array}$} & \multirow{2}{*}{$\begin{array}{l}\text { origin } \\
\text { Jozjan }\end{array}$} & ethnic & \multicolumn{2}{|c|}{ number } & \multirow{2}{*}{$\begin{array}{r}\text { reason } \\
N / A\end{array}$} \\
\hline 21 & Nov & & & $\operatorname{Pr}$ & 135 & $F$ & \\
\hline 24 & Nov & $"$ & Lal & $\mathrm{H}$ & 50 & & poverty \\
\hline 25 & Nov & $"$ & Behsud & $"$ & 25 & & no work \\
\hline 26 & Nov & Angur Ada & Panjao & $"$ & & $\mathbf{F}$ & food, work \\
\hline 26 & Nov & $"$ & $\mathrm{~N} / \mathrm{A}$ & $"$ & 45 & & $\mathrm{~N} / \mathrm{A}$ \\
\hline 26 & Nov & $"$ & $\mathrm{~N} / \mathrm{A}$ & $"$ & $30 *$ & & $\mathrm{~N} / \mathrm{A}$ \\
\hline 26 & Nov & Paktika & Behsud & $"$ & 8 & & food, work \\
\hline 27 & Nov & Urgun & Baghlan & $\mathrm{T}$ & 80 & & $\mathrm{~N} / \mathrm{A}$ \\
\hline 1 & Dec & Jaghatu & Shahristan & $\mathrm{H}$ & 50 & & no work \\
\hline 2 & Dec & $"$ & Behsud & $"$ & 8 & & no work \\
\hline 10 & Dec & Nawur & $N / A$ & $"$ & 30 & & $\mathrm{~N} / \mathrm{A}$ \\
\hline 11 & Dec & Qarabagh & Dai Chopan & $\mathrm{P}$ & & $\star \star$ & food, work \\
\hline $\begin{array}{l}\mathrm{Pr} \\
\mathrm{H} \\
\mathrm{P} \\
\mathrm{T}\end{array}$ & $\begin{aligned} & =\mathrm{P} \\
& =\mathrm{H} \\
& =\mathrm{P} \\
& =\mathrm{T}\end{aligned}$ & $\begin{array}{l}\text { sian speaking } \\
\text { ara } \\
\text { htun } \\
\text { ik }\end{array}$ & & & & & \\
\hline $\begin{array}{l}\mathrm{F} \\
\star\end{array}$ & $\begin{array}{l}=\mathrm{f} \\
\text { inc }\end{array}$ & $\begin{array}{l}\text { lies (if unm } \\
\text { les females }\end{array}$ & arked, the nu & number & refers $t$ & to & individuals) \\
\hline
\end{tabular}


400 jeribs had been damaged, along with many houses," when the earth's plates shifted earlier in the year. He continued: "It is almost certain that if not helped the villagers will have to sell their remaining cattle; then they will have to leave and will become internally displaced."

2. Sheikh Ali district, Parwan. U.N staff members in Bamyan received repeated visits from shura members in this Hazara area requesting immediate help for 400 families whose fields were destroyed following spring floods. The representatives insisted that without outside help the inhabitants would have to leave the area. (Unfortunately, the U.N. is barred from assisting the entire province following a serious security incident involving a commander from Ittehadi Islami (Sayyaf) in the same district in September 1990.)

3. Chagcharan district, Ghor. A prominent elder of the Chahar Aimaq people of central and western Ghor arrived in Lal district during my visit. Also a commander of Jamiat Islami, Rais Babur Murad claimed that thousands of Aimaq families (the Aimaq are considered the poorest of Afghanistan's ethnic groups) were facing acute food shortage because of three years of fighting against Hezb-i Islami (Hekmatyar).

4. Ajrestan district, Uruzgan. Reports from residents visiting Peshawar speak of a food crisis caused by fighting between Hazaras and Pashtuns earlier in the year. Ajrestan is a Pashtun area surrounded by Hazara lands. One tribal leader claimed that half the district's inhabitants had no foodstocks for the winter.

5. Day Chopan district, Zabul. This is another district badly affectyed by the recent Hazara-Pashtun conflict. I encountered commanders from this area in larabagh in December. They were en route to pakistan with letters from shura members requesting immediate assistance from agencies in Peshawar following widespread destruction of homes and the displacement of residents.

Other areas I visited fit the overall characterization of the food situation as borderline but not critical. Food was generaliy more plentiful and cheaper in the east than in the center. Outside of district capitals in central Afghanistan it was difficult to find vegetables other than potatoes, onions, and garlic; fruits of any kind; and eggs. There were chickens in most villages but poultry was not for sale, nor was I ever fed chicken in people's homes. Dairy products - fresh milk, yoghurt, roghan (sharp butter), mascah (buttery cheese) - were available in private homes but not in the bazaars. Animals - goats, sheep, cows - were plentiful in most areas. West and south of Yakaolang wealthier inhabitants own horses. 
Table 3 provides a list of prices of staple foods in Bamyan bazaar from 1987-1990 and an account of food import trens as recorded by Jabha-e Mustazifin, whose base is located at the eastern entrance of Bamyan valley (trucks entering from the western end are not included).

Table 3

Selected commodity prices and food import trends in Bamyan: 1987 - 1990 .

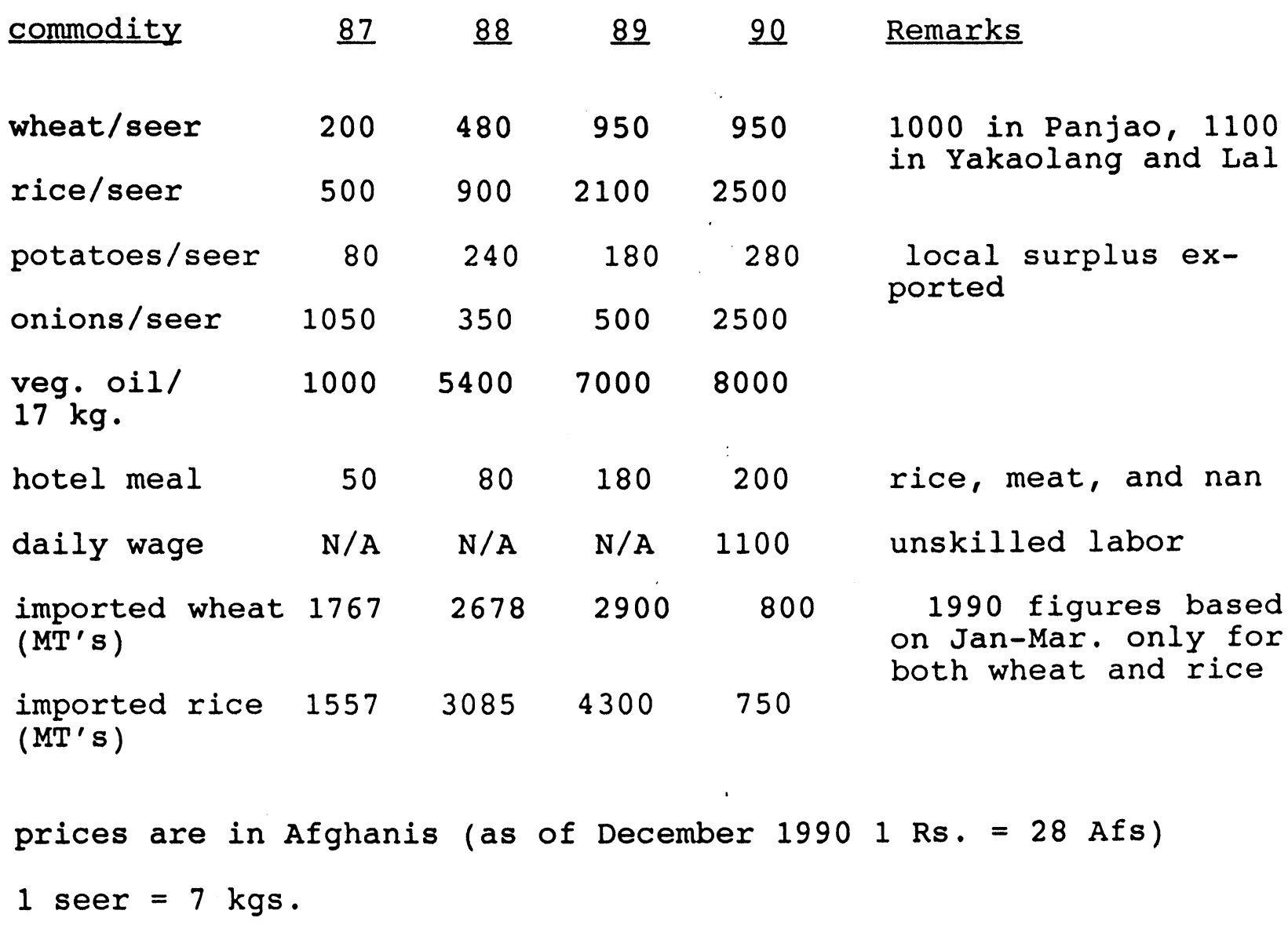


IV. Shuras

Shuras members in areas of Afghanistan I visited are, with a few exceptions, not the "traditional" leaders of the country. I believe that most of the elders of pre-war days have moved to Pakistan and, in some cases, are elders in refugee camps. Afghanistan's new leaders on the local level now are commanders or other figures made prominent by the military conflict. They know how to read and write but are not necessarily the most educated members of the community. The local people may or may not respect them; in any case, in contemporary Afghanistan it is not up to the local people to decide who their representatives are.

Although shuras have component committees - finance, public welfare, reconstruction, etc. - their overwhelming concern is security. They keep loose track over movements in and out of their district. Either the shura or one of its component parties may erect checkposts; the checkpost mujahid may inquire as to the identity or purpose of visit of a passing motorist; he might extract Afs.1000 from a truck driver as a transit tax; or he might drop the rope at the mere toot of a horn.

As self-proclaimed local authorities, shuras also resolve disputes and carry on the functions of the traditional tribal council. They are also a manifestation of political unity; I did not encounter any shura made up of only one party. They are a council of parties active in the area with representation based on the size and strength of each party.

Central Afghanistan has the additional twist that, while each district has a shura composed of several parties, the entire Hazarajat is officially under the control of Hezb-i Wahdat, which does not call itself a "shura." The various shuras I met, except for those in Bamyan and Dahane Abdalla, emphasized their allegiance to Hezb-i Wahdat. Thus, unlike other regions of the country, in Hazarajat shuras are part of an overall regional administration, with each district contributing memembers to the central committee.

By way of illustraton, let us look at two different types of shuras, comparing those found in Bamyan and Qarabagh (Type 1) with those found in Lal and Yakaolang (Type 2). With Type 1, inclusion in the shura stems from military involvement. The shura's range of influence is limited. The Bamyan shura controls the central bazaar and little else; surrounding areas belong to individual parties and to Hezb-i Wahdat. In Qarabagh, a mixed Pashtun-Hazara district, the shura has no influence in the Hazara areas because it has no Hazara representatives.

Because the two shuras contend primarily with security matters, they are not easy to work with in terms of assistance. Their reach is limited, and they do not necessarily know the needs 
of "the people" because they have not been thinking in those terms. Their priority is keeping the enemy, however defined, out of the area and keeping the coalition together.

Lal and Yakaolang, in contrast, have been free from fighting in recent years. The shuras are better organized and more civicminded. They have a much clearer sense of the needs of the local population and of how to meet them. The Lal shura, led by a young cleric named Sajjadi particularly impressed me with its initiative. The Lal shura was not waiting for outside assistance but had started to rebuild - schools, another library, bridges, a clinic on its own. However, part of what gives the Type 2 shura its distinctiveness, other than good leadership, is a favorable political environment. Lal and Yakaolang are both Hezb-i Wahdat strongholds.

The Bamyan shura revealed its shortcomings on several occasions. When I first arrived in Bamyan, for example, the shura told me that it wanted to rehabilitate a school. I asked the shura for a detailed proposal and budget. The following day a commander from a party represented on the shura came to me and said that his party owned the property the school was on, so his party should submit the proposal. I said fine and informed the shura. The shura then discussed the matter with the party, and the latter backed down. Then it took shura members another month to agree on an engineer to make the calculations and submit the proposal.

On my second mission, I brought medicine for the Bamyan hospital. When I informed the shura, its president complained that I had not brought enough for all the clinics in Bamyan and why, he demanded, was I partial to this particular hospital?

On another occasion, I went to check up on wheat stored at the Rubb Hall tent. The tent had been placed at the airport on the advice of the shura. When I arrived, a delegation from Harakat Islami, also represented on the shura, informed me that they controlled the airport and would not allow wheat to be used on projects proposed by the shura.

In Qarabagh, I ventured into Hazara areas twenty minutes behind the bazaar. There, I heard complaints that the shura and the various NGO's and U.N. agencies active in the district knew nothing about Hazara needs because these agencies were all working through the all-Pashtun shura. Moreover, the local Hazara leaders said they were not even allowed into the bazaar. When I raised these issues with shura members, they told me that they knew the situation only too well and that I should stay out of politics and not disturb the unity of the area.

Shuras, however, whether effective or not, are the main political structures on the local level, and they need to be encouraged rather than destabilized by outside aid agencies. At 
17

the very least, shuras represent an attempt to lay aside differences, to take matters into local hands. It is important to work with them rather than circumvent them; aid agencies .particularly those with food and medicine - can use these resources to stretch the responsiveness of shuras to a wider audience, e.g. by encouraging projects outside of district centers and by then monitoring them effectively. 


\section{Delivering Relief Supplies}

Many factors determine whether relief supplies dispatched into Afghanistan will arive safely. The chief issues are the following:

1. Is the aid provider seen to have a bias toward a certain political party or commander?

2. Are the important parties/commanders en route clear about the aid provider's program in the recipient area?

3. Is the recipient willing to assume responsibility for the convoy up to its destination?

4. Are the commodities travelling through areas controlled by a variety of parties and commanders?

During my tenure in Bamyan, the U.N. sent two convoys of wheat to central Afghanistan, one for $100 \mathrm{MT}$ 's and the second for 220 MT's. The first was escorted all the way from Peshawar by the Islamic Shura of Bamyan. More than a dozen shura members went along; they negotiated the route to the Pakistan border without any assistance from the U.N. The U.N. provided per diem to the paticipants and paid the escort leader the full amount for transport charges so that when trucks arrived the drivers could go directly to the shura for payment.

Both the U.N. and the shura underestimated the logistical side of the operation. The U.N. expected the journey from Bamyan to Peshawar and back to take ten days. It took one month. The U.N. expected the problems to arise in pashtun areas. The problems occurred in Hazara areas. The shura, in turn, was simply not organized enough to manage a ten-truck convoy. When the escorts trickled in to Bamyan, everyone had a different story of what happened and why.

In the end $70 \%$ of the dispatch arrived, and it was used immediately in Food for work projects (which have great potential in central Afghanistan). One truck was stopped by a commander from Harakat Islami an hour outside of Bamyan and its load distributed. The U.N. prevailed on its good relations with the main Harakat commander in the area, however, who insisted that his subordinate had made a mistake. About $60 \%$ of the load was eventually recovered.

Another commander from Nasr stopped four trucks from the same convoy at his base outside of Dahane Abdalla. He insisted by letter that U.N. representatives come and discuss projects in his district before he released the wheat. After several delegations from Hezb-i Wahdat failed to resolve the problem, I and one colleague spent two days with the commander and eventually released 
the wheat. The commander had a bone to pick with Hezb-i Wahdat, with whom he perceived the U.N. to be too closely attached, but he was also making a statement that he did not want to see more wheat going up the road unless there were specific plans to leave some for projects in his area.

Our strategy in the second convoy was to use Hezb-i Wahdat as an escort and take a different route. The wheat would go to Yakaolang instead of Bamyan along a route skirting Dahane Abdalla. We negotiated the route ourselves this time, stopping at checkposts and meeting with commanders to introduce the U.N., to explain what kind of assistance we could offer and what we could not, to outline our objectives for central Afghanistan, and to emphasize that our success depended on local cooperation. All the commanders without exception promised their full and unconditional assistance.

The second attempt was more successful. I travelled a day behind the convoy, keeping track of breakdowns and reloading, which were frequent. At one base, whose commander was in Peshawar, young mujahideen took a few bags of wheat from every truck. At another, one truck broke down and a commander simply took half the load into the hills. Nevertheless, we left Yakaolang with 758 of the wheat in hand, with other trucks still on the way.

One can easily make a case from these incidents that Aghanistan is too fragmented and unstable for relief work to be carried out. However, in both convoys I was involved with, the local shuras all took action to assist the U.N.; the shura in the recipient district is especially likely to go the extra mile to get the commodities to the final destination. Shuras will persevere if they get something out of the deal, whether it is wheat, political mileage, or simply recognition.

One very important benefit of aid, consequently, is the potential it has to strenghten local institutions such as shuras. The shura must bear the ultimate responsibility for getting commodities to its area. It is not a small matter when commodities are hijacked, but when it does happen, shuras should go to mobilize to solve the problem. Institution-building is just as important to Afghanistan as building schools and roads. 
V. Final Remarks

While a settlement on Afghanistan as a whole is no closer now than it was a year ago, there have been promising developments on the local level that may allow a measure of security and progress to return to the countryside. The potential for reconstruction and development in central Afghanistan in particular has probably never been brighter since the war began than it is now. The new power broker in Hazarajat, Hezb-i Wahdat, is keen not to squander the opportunity for outside humanitarian assistance; it is also intent on using such assistance to bolster its own position, and to obstruct it vehemently if aid begins to threaten the unity that has taken the shia parties years to nurture.

Yet the rehabilitation of Afghanistan, a country struggling to keep from slipping from the seventeenth to the sixteenth century, is a long-term project, and nowhere is this more evident than in central Afghanistan. The first ingredient is political stability, and there is a glimmer of that now as the parties that fought each other so bitterly in the 1980's struggle to find more common ground.

In the meantime, life in central Afghanistan remains a struggle for all but a handful of people. Educated Hazaras whose beacon is not the kalashnikov see two options for themselves: unemployment or exile. Until there are jobs in central Afghanistan, the educated Hazaras from Jaghori, Behsud, and Kabul will continue to cluster in Quetta and, if they are not too staunchly anti-Iranian, in Iran. Hazara leaders know that this is no long-term solution for their people, and they know it is no longer Najib or the soviets who are responsible for this configuration.

The Hazaras do not have an Ahmad Shah Massoud. They have no leader who has graced the cover of magazines or captured headlines. They have, instead, a plethora of insignificant leaders, a situation that causes Hazara intellectuals in exile great anxiety. It is a situation, they worry, that will provoke Hazaras inside Afghanistan to accept any hand offered.

The Hazaras remain hopeful, meanwhile, that the west will eventually stir from its embrace of "Pashtunism" and look to the interior. They hope that the growing interest in central Afghanistan and the realization that it is a distinct part of the country with different priorities than other areas, reflects such stirrings. 